\title{
Population structure, growth and production of the surf clam Donax serra (Bivalvia, Donacidae) on two Namibian sandy beaches
}

\author{
J. Laudien*, T. Brey, W.E. Arntz \\ Alfred Wegener Institute for Polar and Marine Research, P.O. Box 120161, 27515 Bremerhaven, Germany
}

Received 23 October 2001; accepted 31 July 2002

\begin{abstract}
Population structure, growth and production of the surf clam Donax serra (Bivalvia, Donacidae), inhabiting highly exposed sandy beaches of Namibia, were investigated between November 1997 and December 1999. From length-frequency distribution and tagging-recapture data, a von Bertalanffy growth function with an asymptotic length $\left(L_{\infty}\right)$ of $82 \mathrm{~mm}$ and a growth constant $(K)$ of $0.274 \mathrm{yr}^{-1}$ was established. Regarding growth performance of Donacidae, D. serra fits in a group of species inhabiting cold temperate and upwelling regions. The intertidal biomass of the studied population ranged between 141 and $546 \mathrm{~g}$ ash-free dry mass (AFDM) $\mathrm{m}^{-2} \mathrm{yr}^{-1}$. Individual production was maximal at $56.5 \mathrm{~mm}$ shell length $\left(0.83 \mathrm{~g} \mathrm{AFDM} \mathrm{ind.}{ }^{-1} \mathrm{yr}^{-1}\right)$, and annual production ranged between 167 and $637 \mathrm{~g} \mathrm{AFDM} \mathrm{m}^{-2} \mathrm{yr}^{-1}$, resulting in productivity values $(P / \bar{B})$ between 1.167 and $1.589 \mathrm{yr}^{-1}$. These data underline the importance of $D$. serra for the beach/surf ecosystem. Further, the findings of this study are crucial to support future aquaculture or exploitation activities and management.
\end{abstract}

(c) 2003 Elsevier Ltd. All rights reserved.

Keywords: Donax serra; bivalves; population dynamics; growth; production; intertidal sand habitat; upwelling; Africa West Coast

\section{Introduction}

Bivalves of the family Donacidae inhabit exposed intertidal sandy beaches and form worldwide, by far, the largest group living in such highly dynamic environments (for review, see Ansell, 1983). Members of the genus Donax are commonly the main primary consumers in soft bottom communities, while they are in turn subject to predation by a wide variety of invertebrates, fish, birds and mammals (e.g. Luzzatto \& Penchaszadeh, 2001; Peterson, Hickerson, \& Johnson, 2000; Salas, Tirado, \& Manjon-Cabeza, 2001). Moreover, these clams are important recreational and commercial resources in many countries (McLachlan et al., 1996). Although the abundance is limited by their specialisation to coastal high-energy habitats, Donax species show a

\footnotetext{
* Corresponding author.

E-mail address: jlaudien@awi-bremerhaven.de (J. Laudien).
}

strong adaptive radiation with tidal migration as a common feature. Notwithstanding Ansell's (1983) assertion that donacids are restricted to distinct zoogeographical domains, some species inhabit regions with an overlap of subtropical and temperate zones. Only $5 \%$ of the 64 species are found in cold temperate areas $\left(>5^{\circ} \mathrm{C}\right.$; Bally, 1986), with lowest species diversity on the West Coast of Africa (Ansell, 1983).

The largest-sized donacid Donax serra (Röding, 1798) inhabits the macrozoobenthic community of extended exposed sandy beaches along the Namibian coast and forms dense beds (Donn \& Cockcroft, 1989; McLachlan, 1996). As the surf clam D. serra feeds on phytoplankton and detritus and is consumed by birds, fish and crabs, it is an important trophic link in surf zone food webs (McLachlan et al., 1996; McLachlan, Wooldridge, Schramm, \& Kühn, 1980; Rossouw, 1985; J. Laudien, unpublished data). Furthermore, it is exploited for angling bait, and is of potential value for human consumption. Sims-Castley and Hosking (submitted for publication) calculated a possible price range of 
US\$6.50-60.00 per kg for export markets. Despite its significant ecological role and potential commercial value, few aspects of the population dynamics of the cold temperate Namibian stocks have been investigated, e.g. the reproductive biology (Laudien, Brey, \& Arntz, 2001). Growth rates and population structure were studied elsewhere in southern Africa (Donn, 1986; Schoeman, 1994; de Villiers, 1975), but these results cannot simply be transferred to Namibian populations, since it was reported that populations from the southeast and West Coast of southern Africa differ in behaviour and morphometrics (Donn, 1990; Laudien, Flint, van der Bank, \& Brey, 2003; Soares, Callahan, \& de Ruyck, 1998). Further, genetic differentiation exists between Namibian subpopulations (Laudien et al., 2003). Thus, knowledge of growth parameters and production are essential for the understanding of the ecology and productivity of $D$. serra inhabiting sandy bottoms of the central Benguela upwelling region.
Further, it is crucial to support future aquaculture or exploitation activities and management.

\section{Material and methods}

\subsection{Study site and sampling}

Donax serra were collected during alternate spring tides from two Namibian sandy beaches (Fig. 1), Langstrand $\left(22^{\circ} 47^{\prime} \mathrm{S}, \quad 14^{\circ} 33^{\prime} \mathrm{E}\right)$ and Paaltjies IV $\left(22^{\circ} 59^{\prime} \mathrm{S}, 14^{\circ} 24^{\prime} \mathrm{E}\right)$. According to McLachlan's (1980) rating scale for exposure, Paaltjies IV can be characterised as very exposed and reflective (15.5, mean slope $1 / 24$ ) and Langstrand as exposed and of an intermediate type (13, mean slope $1 / 10)$, being partly recessed behind the sand peninsula Pelican Point (Fig. 1). Both are open ocean beaches receiving continuous wave action. The area is subject to subequal semidiurnal tides, with a

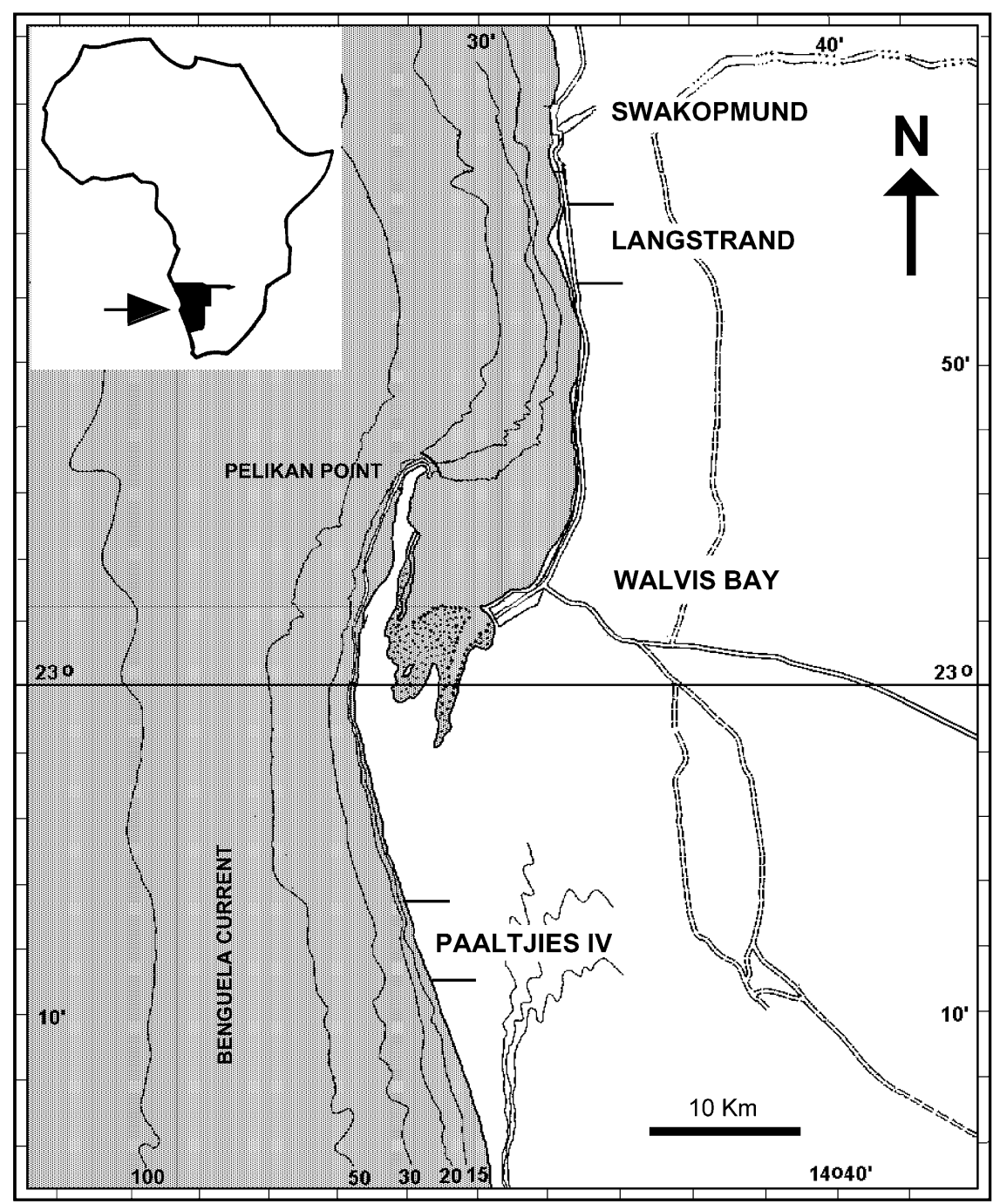

Fig. 1. Map of the study sites 'Langstrand' and 'Paaltjies IV'. 
maximum tide range of $2 \mathrm{~m}$; spring tides average $1.4 \mathrm{~m}$ and neap tides $0.7 \mathrm{~m}$. The sea surface temperature varies between $11^{\circ} \mathrm{C}$ in winter and $23^{\circ} \mathrm{C}$ in summer. Both beaches are composed of well-sorted medium sand, with mean particle diameters ranging at Langstrand between $254 \mu \mathrm{m}$ (low shore) and $291 \mu \mathrm{m}$ (mid-shore) and at Paaltjies IV, between $398 \mu \mathrm{m}$ (low shore) and $255 \mu \mathrm{m}$ (mid-shore), respectively. There is no freshwater seepage at either beach, thus salinity is 35 . Both beaches are well drained and oxygenated. McLachlan (1985) gives a summary including additional features of both beaches.

Donax serra were sampled quantitatively at monthly intervals (Langstrand: November 1997 to November 1999; Paaltjies IV: November 1997 to December 1999) from a series of stations ( $2 \mathrm{~m}$ intervals) along a transect transverse to the shoreline, from the spring tide high water mark to the subtidal of $1 \mathrm{~m}$ water depth. At each station, three replicates of a $0.16 \mathrm{~m}^{2}$ sand sample were excavated to $35 \mathrm{~cm}$ depth using a stirring box, and the sand was sieved on a 1-mm screen. All surf clams were transferred to the laboratory immediately for further investigation. The anterior-posterior length of each individual was measured to the lower $0.1 \mathrm{~mm}$ with vernier callipers. In total, 13,298 clams were measured at Langstrand and 16,305 at Paaltjies IV. Parameters of the relationship between length and mass of $D$. serra were estimated by regression analysis

$M=a L^{b}$

where $M$ is the ash-free dry mass, AFDM (g), obtained by ignition of soft tissue at $550^{\circ} \mathrm{C}$ for $7 \mathrm{~h}, L$ the shell length (mm) and $a$ and $b$ are the constants. AFDM was determined for 400 specimens of all size classes between January and December 1998. For comparisons, all published values were converted to AFDM according to Brey, Rumohr, and Ankar (1988).

\subsection{Growth}

\subsubsection{External and internal shell marks}

Dark lines at the anterior end of the valves of Donax serra (Fig. 2) were counted macroscopically. Microstructural shell deposits commonly reflect tidal, daily or seasonal growth increments and vary consistently in width according to exposure time and temperature (e.g. Gaspar, Ferreira, \& Monteiro, 1999; Richardson, 1989). Therefore, internal shell marks may be suitable for growth analyses. Twenty embedded right valves (between 56 and $82 \mathrm{~mm}$; resin: Metset, Type SW, Buehler 95-B130007) were analysed according to Richardson, Crisp and Runham (1979). Plane sections along the axis of maximum growth were prepared and thereafter grounded on wet grinding paper (P120 followed by P1200). Sections were polished (Mecapol 200 with Meraprex $3 \mu \mathrm{m}$; PRESI, France) and etched in $0.5 \%$

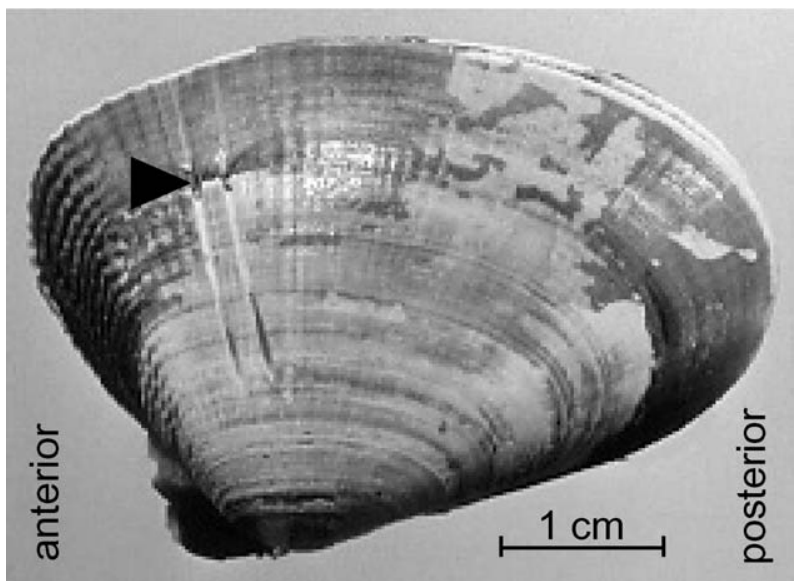

Fig. 2. Right valve of Donax serra recovered on 13 June 1999, 6 months after marking and release. The notch marks (arrow) and growth thereafter show clearly at the valve margin. Estimated growth was $17.6 \mathrm{~mm}$. Additionally, typical dark lines at the anterior edge of the valve can be observed.

DE-CAL ${ }^{\mathrm{TM}}$ (National Diagnostics, Atlanta, GA) for $1 \mathrm{~min}$. Acetate peel replicas were prepared according to Richardson et al. (1979) and examined under a transmitted light microscope (e.g. Gaspar et al., 1999; Richardson, 1989).

\subsubsection{Tagging-recapture experiments}

Individuals (7215) of Donax serra covering the whole size range were collected at Paaltjies IV on three consecutive new moon spring tides in December 1998, January and February 1999. The animals were transported to the laboratory while burrowed in wet sand. Two carborundum discs, $0.7 \mathrm{~mm}$ thick, spaced $2 \mathrm{~mm}$ apart and mounted in the mandrel of an electric grinder, were used to produce distinct parallel, shallow grooves from the ventral margin up onto the valve surface (e.g. Ropes, 1984; Ropes \& Merrill, 1970). The marked clams were released at Paaltjies IV within a rectangular area $(7 \times 5 \mathrm{~m})$. Each individual was put into a $15 \mathrm{~cm}$ deep hole and covered with sediment in order to prevent the clams being carried away by the strong swash. The recapture length and the length at the time of release reflected in a disturbance ring following the notch marks (Fig. 2) were measured. The obtained size increments were used for the estimation of growth parameters (see the subsequent discussion).

\subsubsection{Length-frequency distribution and analyses}

A series of 25 (Langstrand) and 24 (Paaltjies IV) length-frequency distributions $(2 \mathrm{~mm}$ size classes, monthly) were determined. Electronic length-frequency analysis (ELEFAN; Gayanilo, Soriano, \& Pauly, 1989; Pauly \& David, 1981) was not applicable in the present analysis, as it is currently not capable of simultaneously estimating more than one annual growth curve (e.g. Schoeman, personal communication). Cohorts were identified visually, and mean individual length in each 
identified cohort was computed by the weighted average $L_{\text {mean }_{c, t}}$

$L_{\text {mean }_{c, t}}=\frac{\left(L_{j-1} N_{j}\right)+\left(L_{j} N_{j}\right)+\left(L_{j+1} N_{j+1}\right)}{N_{j-1}+N_{j}+N_{j+1}}$

where $N_{j}$ and $L_{j}$ are the number of specimens and midlength of size class $j$, respectively, $j$ the size class with the highest number of individuals and $c$ and $t$ are the indices of cohort and month, respectively.

Growth was described by the von Bertalanffy growth function (VBGF; von Bertalanffy, 1938)

$L_{t}=L_{\infty}\left(1-\mathrm{e}^{-K\left(t-t_{0}\right)}\right)$

where $L_{t}$ is the length at age $t, L_{\infty}$ the asymptotic length $(\mathrm{mm}), t$ the age (yr) and $t_{0}$ is the age at zero length. A rearranged form of the VBGF

$L_{2}=L_{1}+\left(L_{\infty}-L_{1}\right)\left(1-\mathrm{e}^{-K\left(t_{2}-t_{1}\right)}\right)$

was fitted to size-increment data (length $L_{1}$ at $t_{1}$ and $L_{2}$ at $t_{2}$ ) obtained from length-frequency and taggingrecapture data using the non-linear Newton algorithm.

Non-linear functions are sensitive to missing data at either end of the distribution (Pauly, 1983; Wetherall, Polovina, \& Ralson, 1987). As the Langstrand population is exploited and the centre of adult individual distribution is subtidal, larger animals are poorly represented and our samples and data lack size-increment data referring to larger individuals. Therefore, the parameter $L_{\infty}$ was not determined iteratively, but set to $82 \mathrm{~mm}$ according to the maximum length observed.

\subsection{Production}

Total annual production (January-December 1998 and January-December 1999) was calculated for the intertidal Donax serra belt of both beaches by the massspecific growth rate method (Brey, 2001; Crisp, 1984) from the size-mass relation, the size-frequency distribution obtained from all pooled samples and the VBGF

$P=\Sigma N_{i} M_{i} G_{i}\left(\mathrm{~g} \mathrm{AFDM} \mathrm{m}^{-2} \mathrm{yr}^{-1}\right)$

$N_{i}$ and $M_{i}$ are the average number of animals (number per $\mathrm{m}^{2}$ ) and mean individual AFDM in length class $i$, respectively, and $G_{i}$ is the mass-specific growth rate

$G_{i}=b K\left(\left(L_{\infty} / L_{i}\right)-1\right)\left(\mathrm{yr}^{-1}\right)$

where $b$ is the exponent of the size-mass relation, $K, L_{\infty}$ are VBGF parameters and $L_{i}$ is the mean size in class $i$.

Mean annual biomass was computed by

$\bar{B}=\Sigma N_{i} M_{i}\left(\mathrm{~g} \mathrm{AFDM} \mathrm{m}^{-2}\right)$

and annual $P / \bar{B}$ ratios of the Donax serra populations were calculated from annual total production $P$ and annual mean biomass $\bar{B}$.

\section{Results}

\subsection{Growth}

\subsubsection{External and internal shell marks}

The number of macroscopic shell marks at the anterior end of the valves was linearly correlated with shell length $\left(y=0.5 x+4.6, r^{2}=0.93, n=30\right)$. The analyses of microgrowth structures revealed a fine meandric growth line pattern in the outer of three shell layers (outer prismatic, middle crossed lamellar and inner homogeneous/complex crossed lamellar layer) (Fig. 3). The microstructural deposit pattern was neither detectable as discreet increments throughout the shell nor did it show consistent cycles as to be expected from tidal, lunar or annual rhythms.

\subsubsection{Length-frequency distribution and tagging-recapture data}

New cohorts were detected at Langstrand in December 1997, September 1998, May 1999 and August 1999. In 1997, two additional cohorts were evident: September/October (extrapolated) and around April (D. Louw, unpublished data). At Paaltjies IV, one single new cohort was observed during both years in March. Defined cohorts could be tracked up to 13 months resulting in 72 size-increment data pairs (Langstrand 45 pairs, Paaltjies IV 27 pairs; Fig. 4). During the first year of life, a mean length of $35 \mathrm{~mm}$ was reached at both beaches. Only $11(0.15 \%)$ of the 7215 marked Donax serra were recaptured. A common VBGF with a growth constant $K=0.274 \mathrm{yr}^{-1}$ and fixed $L_{\infty}=82 \mathrm{~mm}$ was fitted to the combined data set $\left(r^{2}=0.97\right.$; Fig. 5), as the comparison of residuals from size-increment and tagging-recapture data of both populations and among each other revealed no significant differences.

\subsection{Biomass and production}

Mean annual clam abundance at Langstrand was 96.4 ind. $\mathrm{m}^{-2}$ (1998) and 95.5 ind. $\mathrm{m}^{-2}$ (1999) and at

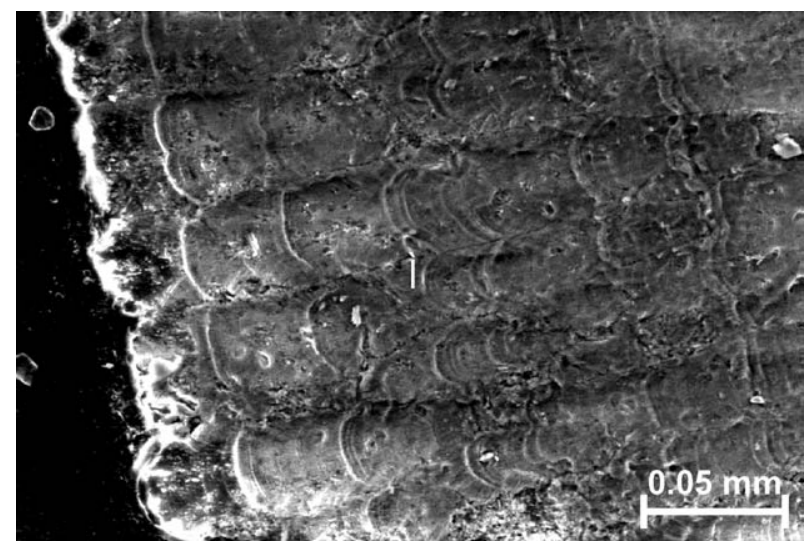

Fig. 3. REM picture of a sectioned valve showing microgrowth bands. 


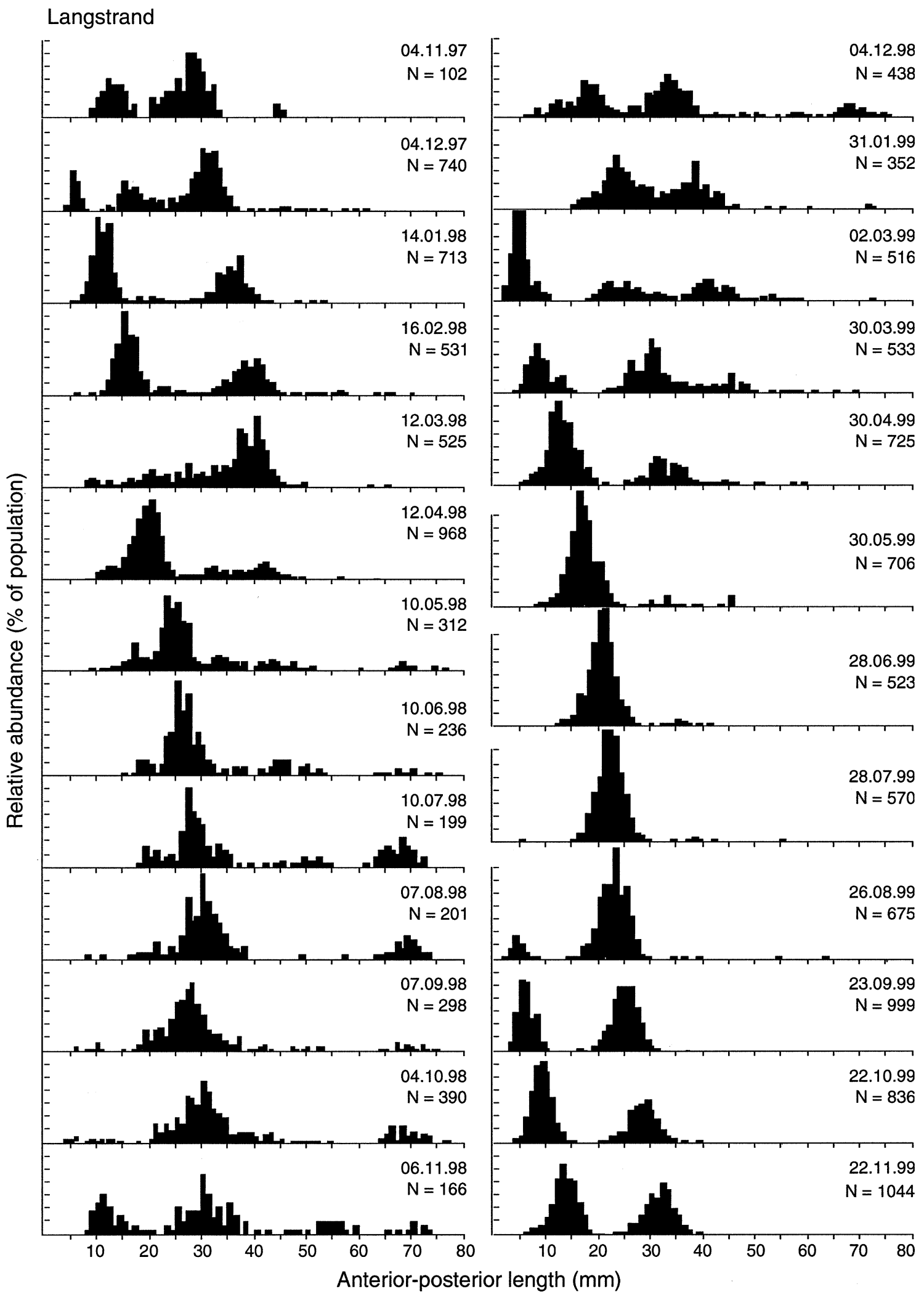

Fig. 4. Monthly length-frequency distribution of Donax serra collected (a) at Langstrand (November 1997 to November 1999) and (b) at Paaltjies (November 1997 to December 1999, except April 1999). Each scale unit on the $y$-axis is equivalent to 2\% of population. 


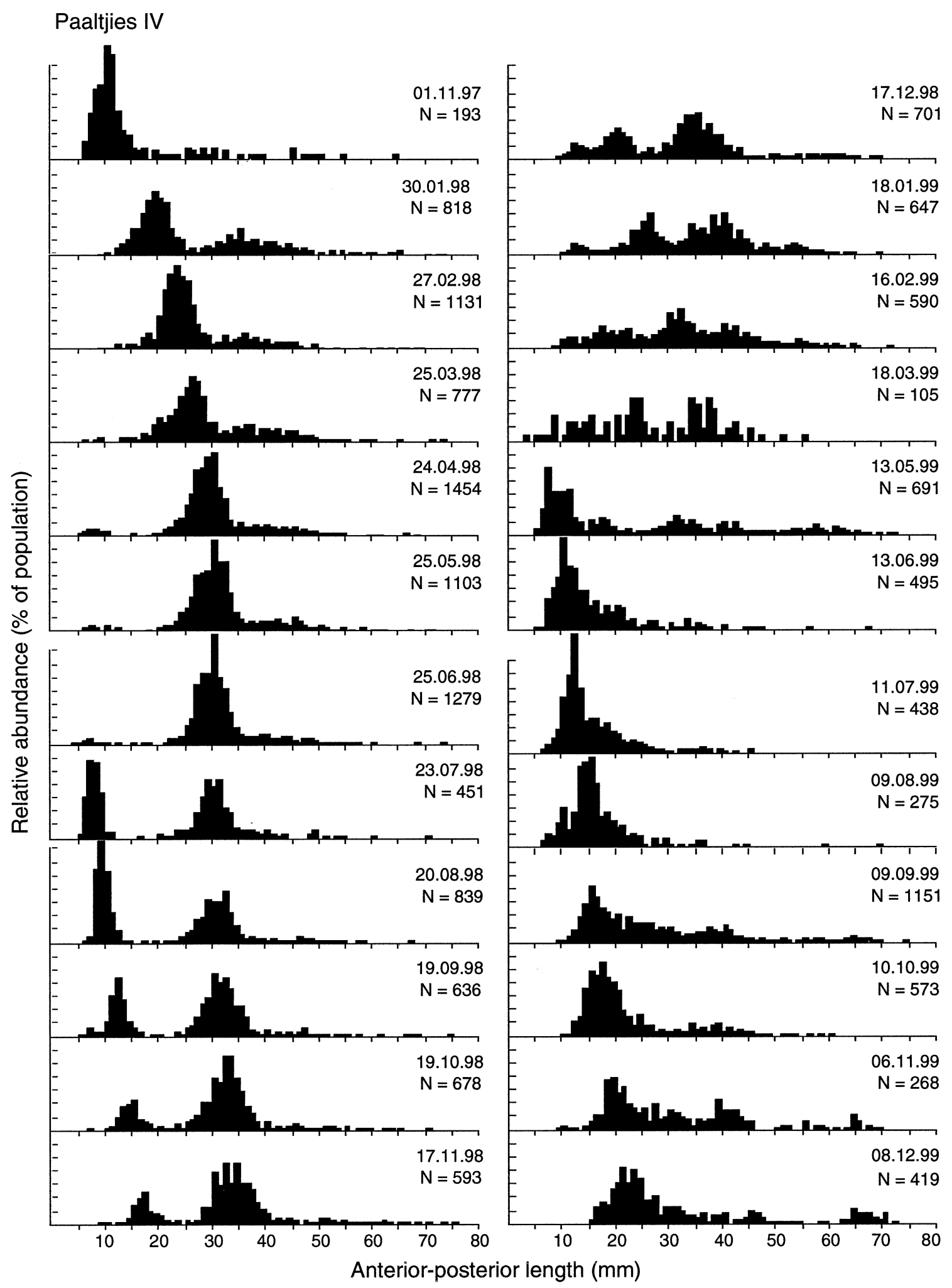

Fig. 4 (continued)

Paaltjies IV, 141.4 ind. $\mathrm{m}^{-2}$ (1998) and 54.9 ind. $\mathrm{m}^{-2}$ (1999), respectively. This represents a mean annual biomass $\bar{B}$ at Langstrand of $288.8 \mathrm{~g} \mathrm{AFDM} \mathrm{m}^{-2}$ (1998) and $171.9 \mathrm{~g} \mathrm{AFDM} \mathrm{m}^{-2}$ (1999) and at Paaltjies IV of $545.9 \mathrm{~g} \mathrm{AFDM} \mathrm{m}^{-2}$ (1998) and $141.2 \mathrm{~g} \mathrm{AFDM} \mathrm{m}^{-2} \mathrm{yr}^{-1}$ (1999) (Fig. 6b-e). 


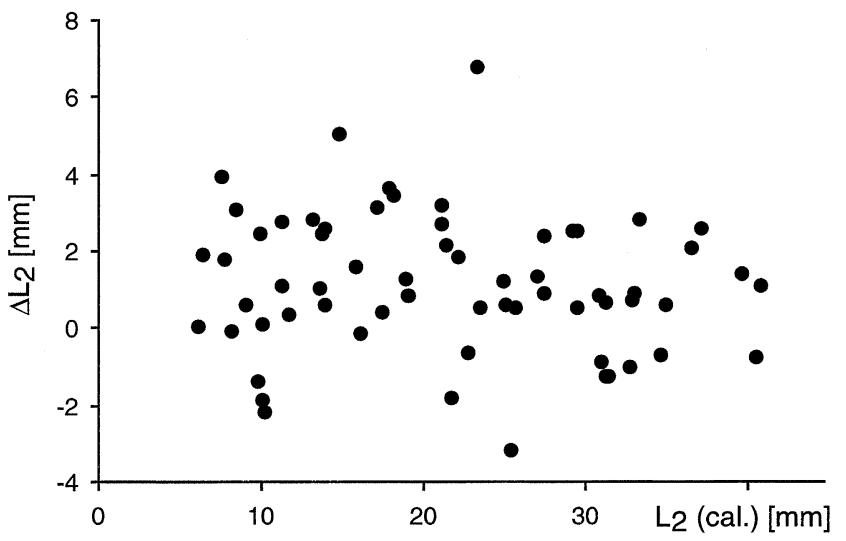

Fig. 5. Residuals of best-fitting von Bertalanffy growth curve of Donax serra; $\Delta L_{2}=L_{2}$ (measured) $-L_{2}$ (calculated).

The observed relationship between length and AFDM of Donax serra $y=4 \times 10^{-6} x^{3.2576}\left(r^{2}=0.96\right.$, $n=965)$ was used for production estimates. Individual production increased to its highest value at $56.5 \mathrm{~mm}$ length ( $0.83 \mathrm{~g} \mathrm{AFDM}$ ind. $\left.{ }^{-1} \mathrm{yr}^{-1}\right)$ and decreased thereafter (Fig. 6a). The distribution of total annual production $P$ and the abundance among the size classes are illustrated in Fig. 6b-e. Annual production ranged between 167 and $637 \mathrm{~g} \mathrm{AFDM} \mathrm{m}^{-2} \mathrm{yr}^{-1}$, depending on beach and year, and $P / \bar{B}$ ratios were between 1.2 and 1.6. In order to convert AFDM to wet mass (WM), the empirical relationship $\mathrm{WM}=13.318 \mathrm{AFDM}(n=400)$ can be used.

\section{Discussion}

\subsection{Growth data and growth}

The analyses of macroscopic lines at the anterior end of the Donax serra valve (Fig. 2) revealed that these structures are linearly correlated with shell length. Previous studies (McLachlan \& Hanekom, 1979; Schoeman, personal communication; de Villiers, 1975) are consistent with our findings that growth of $D$. serra follows a non-linear growth function. Thus, the external stripe pattern is not likely to reflect a temporal pattern.

Microgrowth analyses of Namibian Donax serra are unsuitable for estimate growth. The amplitudes of cyclic growth patterns as observed in Donacidae inhabiting sheltered environments (Nayar, 1955; Ramón \& Richardson, 1992; Wade, 1968) are too small to be detected in the random pattern caused by disturbance events (e.g. continuous strong wave action) for donacids inhabiting exposed habitats. Consequently, uninterpretable microgrowth patterns have been reported for surf zone Donax trunculus (Gaspar et al., 1999; Ramón, Abelló, \& Richardson, 1995) and Donax variabilis (Wilson, 1999). The microgrowth pattern of upwelling donacids is only usable when a prominent disturbance ring can be detected, which follows a strong event (e.g. Benguela Niño, river run-off) and is reflected in the shell structure of all individuals within the population (de Villiers, 1975).

The low recapture rate of $0.15 \%$ in the taggingrecapture experiment is most likely due to natural
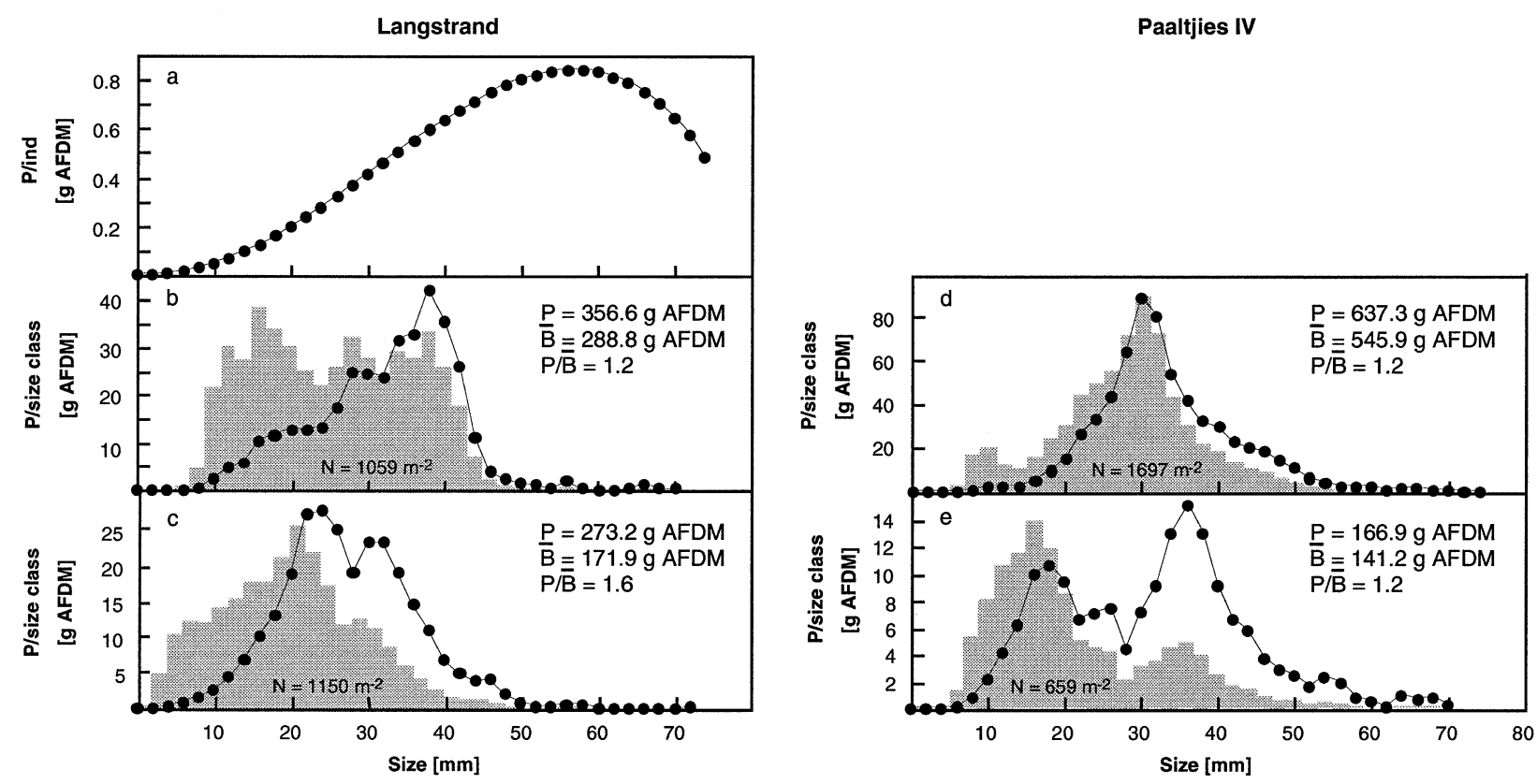

Fig. 6. Distribution of annual somatic individual (a) and population production at Langstrand for 1998 (b) and 1999 (c) and at Paaltjies IV for 1998 (d) and 1999 (e). Additionally, the mean abundance (grey area $=100 \%$ ) for different length classes of Donax serra is included. 
alongshore migration. All marked animals were found in flow direction of the Benguela current up to $450 \mathrm{~m}$ north of the release area. A pilot study with tagged Donax serra revealed as well a significant daily longshore migration (Dugan \& McLachlan, 1999; J. Laudien, unpublished data).

Non-linear growth functions are difficult to compare, whereas several authors (e.g. Moreau, Bambino, \& Pauly, 1986; Munro \& Pauly, 1983; Pauly, 1979) demonstrated the suitability of composite indices for overall growth performance (OGP) for inter- and intraspecific comparisons. The index $P$ is proportional to the maximum rate of body mass increase during lifetime, i.e. the mass increase at the inflexion point of the VBGF, since few values of maximum body mass can be found in the literature and maximal mass is proportional to $L_{\infty}$. The $P$ was calculated by

$P=\log \left(K\left[L_{\infty}\right]^{3}\right)$

OGP of Namibian Donax serra $(P=4.7)$ corresponds well with values calculated from a data set of de Villiers (1975) for two West Coast populations (Elands Bay: $P=4.7$; Melkbosstrand: $P=4.7$ ) (Fig. 7). Our values are also in line with $P$ values computed from data of Schoeman (1997) for a southeast coast population (Maitlands: $P=4.7-5.2$ ). A compilation of donacid OGP data indicated that OGP is habitat-specific (Fig. 7): species inhabiting tropical/subtropical regions show lowest OGP (2.5-3.3, group A), temperate species have intermittent OGP (3.7-4.3, group B), while species of upwelling regions show the highest OGP (4.7-5.2, group C). Growth of suspension feeding bivalves is related to food availability (Jensen, 1992, 1993; Nair, Dalal, \& Ansari, 1978; Nakaoka, 1992; Peterson, 1982; Sastre, 1984; Wade, 1968), which can get limited at exposed sandy beaches (Defeo, Ortiz, \& Castilla, 1992; Lima, Brazeiro, \& Defeo, 2000). Consequently, the high (Jarman \& Carter, 1981; Walsh, 1981) and year-round (Schulz, 1982; Weeks \& Shillington, 1994) primary production in upwelling areas might be the major cause for the observed higher OGP of upwelling donacids.

Another reason may be the narrower annual temperature range of permanent coastal upwelling areas (about $10^{\circ} \mathrm{C}$ ) compared with boreal regions (about $30^{\circ} \mathrm{C}$ ), which facilitates settlement of stenothermic species (e.g. Guillou $\&$ Bayed, 1991). There is evidence that costs of mitochondrial maintenance are lower in stenothermal than in eurythermal species (Pörtner, van Dijk, Hardewig, \& Sommer, 2000). Therefore, low temperature variations might favour growth performance of upwelling donacids.

\subsection{Biomass and production}

Donax serra was the only bivalve inhabiting the studied Namibian beaches. The intertidal biomass of the pop-

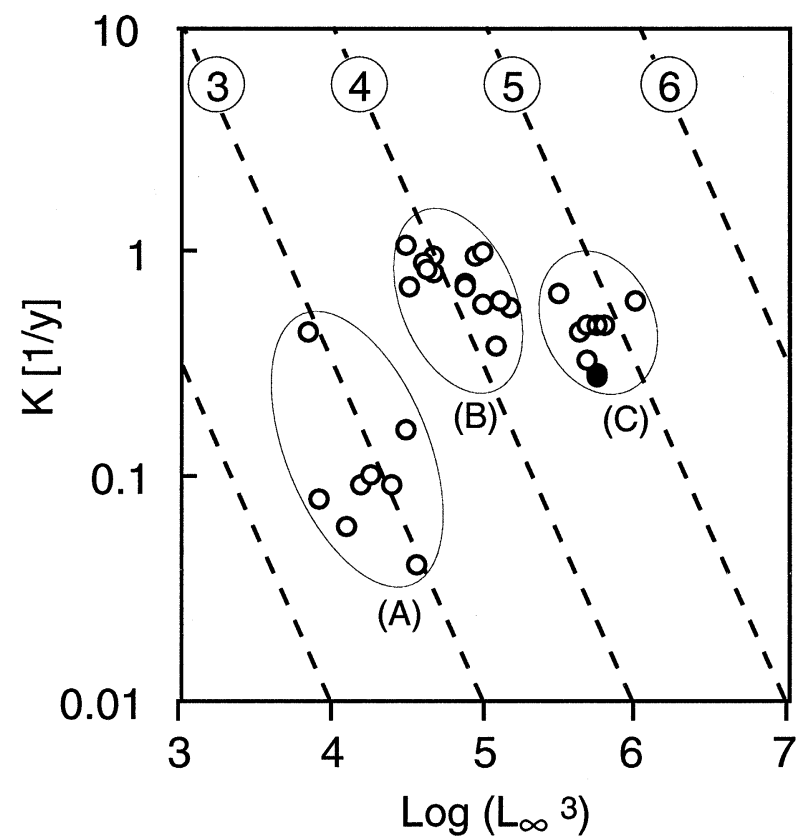

Fig. 7. Auximetric grid (according to Pauly, 1979) comparing OGP index $P=\log \left(K\left[L_{\infty}\right]^{3}\right)$ of several Donacidae $(\bigcirc)$ with Namibian Donax serra $(\bullet)$. Plot indicates three groups (a) tropical/subtropical, (b) temperate and (c) upwelling species. Diagonal lines indicate equal values of $P$ (numbers in circles). Data: (a) Donax cuneatus: Nayar (1955), Talikhedkar, Mane, and Nagabhushanam (1976); Donax incarnatus: Ansell, Sivadas, Narayanan, and Trevallion (1972), Nair et al. (1978), Thippeswamy and Mohan Joseph (1991); Donax faba: Alagarswami (1966); Donax denticulatus: Vélez, Barney, Venables, and Fitzpatrick (1985); (b) Donax trunculus: Ansell and Lagardère (1980), Guillou and Le Moal (1980), Bodoy (1982), Fernández, Otero, and de Coo (1984), Mazé and Laborda (1988), Ramón et al. (1995), Voliani, Auteri, Baino, and Silvestri (1997); Donax vittatus: Ansell and Lagardère (1980); Donax hanleyanus: Defeo (1996); (c) Donax marincovichi: Arntz et al. (1987); D. serra: de Villiers (1975), Farquhar (1996), Schoeman (1997), present study.

ulation ranged between 141 and $546 \mathrm{~g} \mathrm{AFDM} \mathrm{m}^{-2} \mathrm{yr}^{-1}$ (Fig. 6). Taking into account the fact that the centre of the adult specimen distribution is likely to be situated in the subtidal (Donn, 1990; Soares et al., 1998), our estimate of intertidal biomass has to be considered conservative regarding the entire population. However, our value is much higher than in D. serra at warm temperate (South Africa) beaches (27g AFDM, McLachlan et al., 1981; $754 \mathrm{~g} \mathrm{AFDM} \mathrm{m}^{-1}$ beach line, McLachlan \& Hanekom, 1979). Schoeman's value of $1731 \mathrm{~g}$ shell free dry mass per meter beach line corresponds to $48 \mathrm{~g} \mathrm{AFDM} \mathrm{m}^{-2} \mathrm{yr}^{-1}$ in the Donax-belt ( $30 \mathrm{~m}$ belt width, D. Schoeman, personal communication; AFDM $=0.831 \mathrm{DM}$, Brey, 2001). Apparently, the biomass reached by $D$. serra inhabiting the upwelling system distinctly exceeds the range reported for several non-upwelling Donax species $(0.1-2.0 \mathrm{~g}$ AFDM m$^{-2}$; Ansell, McLusky, Stirling, \& Trevallion, 1978; Mazé, 1990; McLachlan et al., 1981; McLachlan \& van der Horst, 1979; Warwick, George, \& Davies, 1978; Wilson, 1999). From the South American Humboldt upwelling system, again higher values are feasible: 
70 g AFDM for Donax marincovichi (Tarazona, Arntz, Canahuire, Ayala, \& Robles, 1985), formerly called Donax peruvianus. High biomass was also reported for the surf clam Mesodesma donacium $\left(910 \mathrm{~g} \mathrm{AFDM} \mathrm{m}^{-2}\right.$; Arntz, Brey, Tarazona, \& Robles, 1987), which is very similar in shape and size to D. serra and plays a comparable ecological role in the Humboldt ecosystem.

The annual intertidal production of Donax serra ranged between 167 and $637 \mathrm{~g} \mathrm{AFDM} \mathrm{m}^{-2} \mathrm{yr}^{-1}$ at Paaltjies IV and between 273 and $357 \mathrm{~g} \mathrm{AFDM} \mathrm{m}^{-2} \mathrm{yr}^{-1}$ at Langstrand. These values are significantly higher than values of $34-46 \mathrm{~g} \mathrm{AFDM} \mathrm{m}^{-2} \mathrm{yr}^{-1}$, calculated from habitats without permanent upwelling at the Eastern Cape of South Africa (Schoeman, personal communication) and converted to $\mathrm{g}$ AFDM m $\mathrm{m}^{-2} \mathrm{yr}^{-1}$ (see previous discussion). The presented values also distinctly exceed those of non-upwelling donacids. Ansell et al. (1978) found production values of 2.9 and $3.3 \mathrm{~g} \mathrm{AFDM} \mathrm{m}^{-2} \mathrm{yr}^{-1}$ for tropical (India) Donax incarnatus and Donax spiculum, respectively. Warm temperate Donax variabilis produced 6.0 $\mathrm{g} \mathrm{AFDM} \mathrm{m}^{-2} \mathrm{yr}^{-1}$ (Wilson, 1999), Donax trunculus produced between 1.8 and $3.7 \mathrm{~g} \mathrm{AFDW} \mathrm{m}^{-2}$ $\mathrm{yr}^{-1}$ (Mazé, 1990) and production of temperate Donax vittatus was $0.7 \mathrm{~g} \mathrm{AFDM} \mathrm{m}^{-2} \mathrm{yr}^{-1}$ (Warwick et al., 1978). To our knowledge, there is currently no information available on production for Donacidae from permanent upwelling areas, but Mesodesma donacium from the Humboldt upwelling system has even higher production rates (2400 $\mathrm{g} \mathrm{AFDM} \mathrm{m}^{-2} \mathrm{yr}^{-1}$; Arntz et al., 1987). Therefore, upwelling habitats seem to favour higher production rates presumably due to year-round food availability, high food quality and low temperature ranges around the optimal temperature, on which clams are adapted (Pörtner et al., 2000).

Production/biomass $(P / \bar{B})$ ratios of Donax serra ranged between 1.167 and $1.589 \mathrm{yr}^{-1}$. These values are slightly higher than those of warm temperate South African D. serra $\left(0.63-1.06 \mathrm{yr}^{-1}\right.$; Schoeman, personal communication), but correspond to Donax sordidus (1.30-1.78 $\mathrm{yr}^{-1}$; McLachlan, 1979; McLachlan \& van der Horst, 1979) and Donax trunculus (1.37-2.26 $\mathrm{yr}^{-1}$; Mazé, 1990). As the subtidal adults are not accounted for in our calculation and, additionally, exploitation concentrates on large clams, the size-frequency distribution is biased towards smaller individuals with high somatic productivity ratios (see also Urban \& Campos, 1994).

Donacids play different roles in different habitats. On tropical beaches (Venezuela), Donax denticulatus dominates benthic biomass, but only accounts for a comparatively low portion $(5 \%)$ of the total production (Ansell, 1983). In comparison, the combined contribution of Indian Donax incarnatus and Donax spiculum to macrobenthic production ranged between 56 and $61 \%$ (Ansell et al., 1978). In temperate shallow water habitats of the Bristol Channel (UK), Donax vittatus only accounts for $0.75 \%$ of the benthic biomass; a high mass-specific production rate, however, ensures that it ranks among the top five secondary producers in the community (Warwick et al., 1978). At the warm temperate South African east coast, Donax serra is responsible for $94 \%$ of macrobenthic production, while Donax sordidus contributes only $2.5 \%$ (McLachlan et al., 1981). The role of $D$. serra in the beach/surf zone ecosystems is important, as it significantly contributes to the regeneration of dissolved and particulate organic nitrogen (Cockcroft \& McLachlan, 1993). Part of the secondary production by this clam is consumed by crabs, birds and benthos feeding fish (McLachlan et al., 1980, 1996; Rossouw, 1985; J. Laudien, unpublished data), which makes $D$. serra an essential trophic link in the coastal upwelling ecosystem. Along with high abundance and production rate and its use as bait and potential economic value for export markets (Sims-Castley \& Hosking, submitted for publication), D. serra is apparently a valuable species for aquaculture. Future research should evaluate the possibility to rear $D$. serra. Further, ageing methods, which are independent of variable environmental factors (e.g. isotopic age determination) should be focussed on.

\section{Acknowledgements}

This work is part of a $\mathrm{PhD}$ project partly funded by 'Deutscher Akademischer Austauschdienst (DAAD)' and by the University of Bremen. It was supported through the Namibian-German cooperation by 'Deutsche Gesellschaft für Technische Zusammenarbeit (GTZ)'. The Namibian Ministry of Fisheries and Marine Resources kindly provided laboratory and office facilities to JL. Thanks are expressed to the staff of the National Information and Research Centre (NatMIRC) for friendly and helpful support. We are also grateful to Dr Chris Richardson and Andreas Schmidt for their help with the acetate peel method. Two anonymous reviewers gave valuable comments on an earlier draft of the manuscript.

\section{References}

Alagarswami, K. (1966). Studies on some aspects of biology of the wedge-clam Donax faba Gmelin from Mandapam coast in the Gulf of Mannar. Journal of the Marine Biological Association of India 8, 56-75.

Ansell, A. D. (1983). The biology of the genus Donax. In A. McLachlan, T. Erasmus, \& W. Junk (Eds.), Developments in hydrobiology, Sandy beaches as ecosystems Vol. 19 (pp. 607-635). The Hague: Junk.

Ansell, A. D., \& Lagardère, F. (1980). Observations on the biology of Donax trunculus and D. vittatus at Ile d'Oléron (French Atlantic coast). Marine Biology 57, 287-300.

Ansell, A. D., McLusky, D. S., Stirling, A., \& Trevallion, A. (1978). Production and energy flow in the macrobenthos of two sandy beaches in south west India. Proceedings of the Royal Society of Edinburgh 76B, 269-296. 
Ansell, A. D., Sivadas, P., Narayanan, B., \& Trevallion, A. (1972). The ecology of two sandy beaches in south west India. III. Observations on the population of Donax incarnates and D. spiculum. Marine Biology 17, 318-332.

Arntz, W. E., Brey, T., Tarazona, J., \& Robles, A. (1987). Changes in the structure of a shallow sandy-beach community in Peru during El Niño events. In A. I. L. Payne, J. A. Gulland, \& K. H. Brink (Eds.), The Benguela and comparable ecosystems. South African Journal of Marine Science 5, 645-658.

Bally, R. (1986). The biogeography of Donax (Mollusca; Bivalvia). In T. E. Donn (Ed.), Biology of the genus Donax in southern Africa, Institute of Coastal Research, University of Port Elizabeth report 5 (pp. 7-12). Institute of Coastal Research, University of Port Elizabeth.

von Bertalanffy, L. (1938). A quantitative theory of organic growth. Human Biology 10, 181-213.

Bodoy, A. (1982). Croissance saisonnière du bivalve Donax trunculus (L.) en Méditerranée nordoccidentale (France). Malacologia 22, 353-358.

Brey, T. (2001). Population dynamics in benthic invertebrates. A virtual handbook. Alfred Wegener Institute for Polar and Marine Research, Germany. Available: http://www.awi-bremerhaven.de/Benthic/Ecosystem/FoodWeb/Handbook/main.html.

Brey, T., Rumohr, H., \& Ankar, S. (1988). Energy content of macrobenthic invertebrates: general conversion factors from weight to energy. Journal of Experimental Marine Biology and Ecology 117, 271-278.

Cockcroft, A. C., \& McLachlan, A. (1993). Nitrogen budget for a high energy ecosystem. Marine Ecology Progress Series 100, 287-299.

Crisp, D. J. (1984). Energy flow measurements. In N. A. Holme, \& A. D. McIntyre (Eds.), Methods for the study of marine benthos, 2nd ed. (pp. 284-372). Oxford: Blackwell.

Defeo, O. (1996). Experimental management of an exploited sandy beach bivalve population. Revista Chilena de Historia Natural 69, 605-614.

Defeo, O., Ortiz, E., \& Castilla, J. C. (1992). Growth, mortality and recruitment of the yellow clam Mesodesma mactroides on Uruguayan beaches. Marine Biology 114, 429-437.

Donn, T. E. (1986). Growth, production and distributional dynamics of the white mussel, Donax serra, in the Eastern Cape. In T. E. Donn (Ed.), Biology of the genus Donax in Southern Africa, Institute of Coastal Research, University of Port Elizabeth report 5 (pp. 34-41). Institute of Coastal Research, University of Port Elizabeth.

Donn, T. E. (1990). Morphometrics of Donax serra Röding (Bivalvia: Donacidae) populations with contrasting zonation. Journal of Coastal Research 6, 893-901.

Donn, T. E., \& Cockcroft, A. C. (1989). Macrofaunal community structure and zonation of two sandy beaches on the central Namib coast, South West Africa/Namibia. Madoqua 16, 129-135.

Dugan, J. E., \& McLachlan, A. (1999). An assessment of longshore movement in Donax serra Röding (Bivalvia: Donacidae) on an exposed sandy beach. Journal of Experimental Marine Biology and Ecology 234, 111-124.

Farquhar, M. (1996). Stock assessment and population dynamics of the white mussel, Donax serra (83 pp.). Report, Zoology Department, University of Cape Town.

Fernández, J., Otero, J., \& de Coo, A. (1984). Contribución al estudio de la cocquina (Donax trunculus L.) en Galicia. Actas do IV Simposio Ibérico do Estudos do Benthos marinho 2, 133-142.

Gaspar, M. B., Ferreira, R., \& Monteiro, C. C. (1999). Growth and reproductive cycle of Donax trunculus L., (Mollusca: Bivalvia) off Faro, southern Portugal. Fisheries Research 41, 309-316.

Gayanilo, F. C., Soriano, M., \& Pauly, D. (1989). A draft guide to the complete ELEFAN (pp. 1-70). ICLARM report 435.

Guillou, J., \& Bayed, A. (1991). Contraintes du milieu sur les populations de Donax trunculus L. et Donax venustus Poli du littoral atlantique marocain. Oceanologica Acta 14, 291-298.
Guillou, J., \& Le Moal, Y. (1980). Aspects de la dynamique des populations de Donax trunculus et Donax vittatus en baie de Douarnenez, Annales de l'Institut Océanographique. Paris 56, 55-64.

Jarman, N. G., \& Carter, R. A. (1981). The primary producers of the inshore regions of the Benguela. Transactions of the Royal Society of South Africa 44, 321-325.

Jensen, K. T. (1992). Dynamics and growth of the cockle, Cerastoderma edule, on an intertidal mud-flat in the Danish Wadden Sea: effects of submersion time and density. Netherlands Journal of Sea Research 28, 335-345.

Jensen, K. T. (1993). Density-dependent growth in cockles (Cerastoderma edule): evidence from interannual comparisons. Journal of the Marine Biological Association of the United Kingdom 73, 333-342.

Laudien, J., Brey, T., \& Arntz, W. E. (2001). Reproduction and recruitment patterns of the surf clam Donax serra (Bivalvia, Donacidae) of two Namibian sandy beaches. South African Journal of Marine Science 23, 53-60 (Special volume).

Laudien, J., Flint, N. S., van der Bank, F. H., \& Brey, T. (2003). Genetic and morphological variation in four populations of the surf clam Donax serra (Röding) from southern African sandy beaches. Biochemical Systematics and Ecology 31, 751-772.

Lima, M., Brazeiro, A., \& Defeo, O. (2000). Population dynamics of the yellow clam Mesodesma mactroides: recruitment variability, density-dependence and stochastic processes. Marine Ecology Progress Series 207, 97-108.

Luzzatto, D. C., \& Penchaszadeh, P. E. (2001). Regeneration of the inhalant siphon of Donax hanleyanus (Philippi, 1847) (Bivalvia, Donacidae) from Argentina. Journal of Shellfish Research 20, 149-153.

Mazé, R. A. (1990). Estimación de la producción del bivalvo marino Donax trunculus L. en la ría de in El Barquero estuary (Galicia) - estimation of secondary production of the marine bivalve Donax trunculus L. in El Barquero estuary (Galicia). Iberus 9, 155-160.

Mazé, R. A., \& Laborda, A. J. (1988). Aspectos de la dinámica de población de Donax trunculus (Linnaeus, 1758) (Bivalvia: Donacidae) en la ría de El Barquero (Lugo, NO España). Investigacion pesquera 52, 299-312.

McLachlan, A. (1979). Growth and production of Donax sordidus Hanley on an open sandy beach in Algoa Bay. South African Journal of Zoology 14, 61-66.

McLachlan, A. (1980). The definition of sandy beaches in relation to exposure: a simple rating system. South African Journal of Science 76, 137-138.

McLachlan, A. (1985). The ecology of two sandy beaches near Walvis Bay. Madoqua 14, 155-163.

McLachlan, A. (1996). Physical factors in benthic ecology: effects of changing particle size on beach fauna. Marine Ecology Progress Series 131, 205-217.

McLachlan, A., Dugan, J. E., Defeo, O., Ansell, A. D., Hubbard, D. M., Jaramillo, E., \& Penchaszadeh, P. (1996). Beach clam fisheries. In A. D. Ansell, R. N. Gibson, \& M. Barnes (Eds.), Oceanography and marine biology: An annual review Vol. 34 (pp. 163-232). London: UCL Press.

McLachlan, A., Erasmus, T., Dye, A. H., Wooldridge, T., van der Horst, G., Rossouw, G., Lasiak, T. A., \& McGwynne, L. (1981). Sandy beach energetics: an ecosystem approach towards a high energy interface. Estuarine, Coastal and Shelf Science 13, 11-25.

McLachlan, A., \& Hanekom, N. (1979). Aspects of the biology, ecology and seasonal fluctuations in biochemical composition of Donax serra in the East Cape. South African Journal of Zoology 14, 183-193.

McLachlan, A., \& van der Horst, G. (1979). Growth and reproduction of two molluscs from an exposed sandy beach. South African Journal of Zoology 14, 194-201.

McLachlan, A., Wooldridge, T., Schramm, T., \& Kühn, M. (1980). Seasonal abundance, biomass and feeding of shore birds on sandy beaches in the Eastern Cape, South Africa. Ostrich 51, 44-52. 
Moreau, J., Bambino, C., \& Pauly, D. (1986). Indices of overall growth performance of 100 tilapia (Cichlidae) populations. In J. L. Maclean, L. B. Dizon, \& L. V. Hosillos (Eds.), The first Asian fisheries forum (pp. 201-206). Manila: Asian Fisheries Society.

Munro, J. L., \& Pauly, D. (1983). A simple method for comparing the growth of fishes and invertebrates. Fishbyte 1, 5-6.

Nair, A., Dalal, S. G., \& Ansari, Z. A. (1978). Growth of the beach clam Donax incarnates Gmelin from a sandy beach at Benaulim, Goa. Indian Journal of Marine Sciences 7, 197-199.

Nakaoka, M. (1992). Spatial and seasonal variation in growth rate and secondary production of Yolida notabilis in Otsuchi Bay, Japan, with reference to the influence of food supply from the water column. Marine Ecology Progress Series 88, 215-223.

Nayar, K. N. (1955). Studies on the growth of the wedge clam Donax (Latona) cuneatus Linnaeus. Indian Journal of Fisheries 2, 325-348.

Pauly, D. (1979). Gill size and temperature as governing factors in fish growth: a generalization of von Bertalanffy's growth formula. Berichte aus dem Institut für Meereskunde Kiel 63, 1-156.

Pauly, D. (1983). Some simple methods for the assessment of tropical stocks. FAO Fisheries Technical Paper 234, 1-52.

Pauly, D., \& David, N. (1983). ELEFAN I, a BASIC program for the objective extraction of growth parameters from length-frequency data. Meeresforschung 28, 205-211.

Peterson, C. H. (1982). The importance of predation and intra- and interspecific competition in the population biology of two infaunal suspension-feeding bivalves, Protothaca staminea and Chione undatella. Ecological Monographs 52, 437-475.

Peterson, C. H., Hickerson, D. H. M., \& Johnson, G. G. (2000). Shortterm consequences of nourishment and bulldozing on the dominant large invertebrates of a sandy beach. Journal of Coastal Research 16, 368-378.

Pörtner, H. O., van Dijk, P. L. M., Hardewig, I., \& Sommer, A. (2000). Levels of metabolic cold adaptation: tradeoffs in eurythermal and stenothermal ectotherms. In C. Davison, P. Howard-Williams, \& P. Broady (Eds.), Antarctic ecosystems: Models for wider ecological understanding (pp. 109-122). Christchurch: Caxton Press.

Ramón, M., Abelló, P., \& Richardson, C. A. (1995). Population structure and growth of Donax trunculus (Bivalvia: Donacidae) in the western Mediterranean. Marine Biology 121, 665-671.

Ramón, M., \& Richardson, C. A. (1992). Age determination and shell growth of Chamelea gallina (Bivalvia: Veneridae) in the western Mediterranean. Marine Ecology Progress Series 89, 15-23.

Richardson, C. A. (1989). An analysis of the growth bands in the shell of the common mussel Mytilus edulis. Journal of the Marine Biological Association of the United Kingdom 69, 477-491.

Richardson, C. A., Crisp, D. J., \& Runham, N. W. (1979). Tidally deposited growth bands in the shell of the common cockle Cerastoderma edule (L.). Malacologia 18, 277-290.

Ropes, J. W. (1984). Procedures of preparing acetate peels and evidence validating the annual periodicity of growth lines formed in the shells of Ocean Quahogs, Arctica islandica. Marine Fisheries Review 46, 27-35.

Ropes, J. W., \& Merrill, A. S. (1970). Marking surf clams. Proceedings of the National Shellfish Association 60, 99-106.

Rossouw, G. J. (1985). Prey selection and competition between surfzone benthic feeding fishes. South African Journal of Science 81, 702.

Salas, C., Tirado, C., \& Manjon-Cabeza, M. E. (2001). Sublethal footpredation on Donacidae (Mollusca: Bivalvia). Journal of Sea Research 46, 43-56.

Sastre, M. P. (1984). Relationship between environmental factors and Donax denticulatus populations in Puerto Rico. Estuarine, Coastal and Shelf Science 19, 217-230.

Schoeman, D. S. (1994). Preliminary results from a survey on Donax serra in the Eastern Cape. In L. E. McGwynne (Ed.), White sand mussels: Ecology, status and conservation, Institute of Coastal Research, University of Port Elizabeth report 36 (pp. 14-16). Institute of Coastal Research, University of Port Elizabeth.
Schoeman, D. S. (1997). Spatial and temporal dynamics of Donax serra in St Francis Bay: Implications for a potential fishery (200 pp.). $\mathrm{PhD}$ thesis, University of Port Elizabeth, South Africa.

Schulz, S. (1982). A comparison of primary production in upwelling regions off northwest and southwest Africa. In G. Hempel (Ed.), The canary current: Studies of an upwelling system. A symposium held in Las Palmas, 11-14 April 1978. Rapports et Proces-Verbaux des Réunions Commission International pour l'Exploration Scientifique de la Mer Mediterranee Monaco 180, 202-204.

Sims-Castley, R., \& Hosking, S. G. A social cost-benefit analysis of a small-scale clam fishery in the Eastern Cape. South African Journal of Marine Science, submitted for publication.

Soares, A. G., Callahan, R. K., \& de Ruyck, A. M. C. (1998). Microevolution and phenotypic plasticity in Donax serra Röding (Bivalvia: Donacidae) on high energy sandy beaches. Journal of Molluscan Studies 64, 407-421.

Talikhedkar, P. M., Mane, U. H., \& Nagabhushanam, R. (1976). Growth rate of the wedge clam Donax cuneatus at Miriya Bay, Ratnagiri. Indian Journal of Fisheries 23, 183-193.

Tarazona, J., Arntz, W. E., Canahuire, E., Ayala, Z., \& Robles, A. (1985). Modificaciones producidas durante 'El Niño' en la infauna bentónica de areas someras del ecosistema de afloramiento peruano. In W. Arntz, A. Landa, \& J. Tarazona (Eds.), 'El Niño' Su Impacto en la Fauna Marina, Boletín Instituto del Mar del Peru (pp. 55-63). (Volumen extraordinario).

Thippeswamy, S., \& Mohan Joseph, M. (1991). Population selection strategies in the wedge clam, Donax incarnates (Gmelin) from Panambur beach, Mangalore. Indian Journal of Marine Sciences 20, 147-151.

Urban, H.-J., \& Campos, B. (1994). Population dynamics of the bivalves Gari solida, Semele solida and Protothaca thaca from a small bay in Chile at $36^{\circ} \mathrm{S}$. Marine Ecology Progress Series 115, 93-102.

de Villiers, G. (1975). Growth, population dynamics, a mass mortality and arrangement of white sand mussels, Donax serra Röding, on beaches in the south-western Cape province (pp. 1-31). Sea fisheries branch investigational report. Republic of South Africa Department of Industries, 109.

Vélez, A., Barney, J., Venables, J., \& Fitzpatrick, L. C. (1985). Growth and production of the tropical beach clam Donax denticulatus (Tellinidae) in eastern Venezuela. Caribbean Journal of Science 21, 63-73.

Voliani, A., Auteri, R., Baino, R., \& Silvestri, R. (1997). Insediamento nel substrato ed accrescimento di Donax trunculus L. sul litorale Toscano - settlement and growth of Donax trunculus L. along the Tuscanian Coast. Biologia Marina Mediterranea 4, 458-460.

Wade, B. A. (1968). Studies on the biology of the West Indian beach clam, Donax denticulatus Linné. 2. Life-history. Bulletin of Marine Science 18, 876-901.

Walsh, J. J. (1981). A carbon budget for overfishing off Peru. Nature 290, 300-304.

Warwick, R. M., George, C. L., \& Davies, J. R. (1978). Annual macrofauna production in a Venus community. Estuarine and Coastal Marine Science 7, 215-241.

Weeks, S. J., \& Shillington, F. A. (1994). Interannual scales of variation of pigment concentrations from coastal zone scanner data in the Benguela upwelling system and the subtropical convergence zone south of Africa. Journal of Geophysical Research 99(C), 73857399.

Wetherall, J. A., Polovina, J. J., \& Ralson, S. (1987). Estimating growth and mortality in steady-state fish stocks from lengthfrequency data. In D. Pauly, \& G. R. Morgan (Eds.), Length-based methods in fisheries research (pp. 53-74). Manila: ICLARM.

Wilson, J. G. (1999). Population dynamics and energy budget for a population of Donax variabilis (Say) on an exposed South Carolina beach. Journal of Experimental Marine Biology and Ecology 239, 61-83. 